\title{
SEEKING PLURALISM IN JUDICIAL SYSTEMS: THE AMERICAN EXPERIENCE AND THE SOUTH AFRICAN CHALLENGE
}

\author{
A. LeON Higginbotham, JR. $\uparrow$ \\ TABLE OF CONTENTS
}

INTRODUCTION . . . . . . . . . . . . . . . . . . 1030

I. The Public Perception PRoblems of aN

UNREPRESENTATTVE JUDICIARY . . . . . . . . 1033

A. The Public's Perception of the Judiciary . . . . 1035

B. The Judiciary's Problem of Perception of the

Public, or "The Prejudices Judges Share with

Their Fellow Men" . . . . . . . . . . . . . . 1040

II. THE OUTGROWTHS OF PREJUdICE IN THE

JUDICIAL SYSTEMS OF THE UNITED STATES

AND SOUTH AFRICA . . . . . . . . . . . . . . 1042

III. THE UNITED STATES' EXPERIENCE IN THE

APPOINTMENT OF FEDERAL JUDGES . . . . . . . 1048

IV. THE NECESSITY OF A VIABLE SOUTH AFRICAN

BILl of RIGHTS AND A WIDESPREAD PERCEPTION

OF JUDICIAL FAIRNESS . . . . . . . . . . . . 1058

V. Conclusion . . . . . . . . . . . . 1060

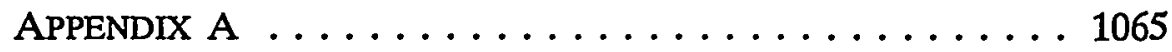

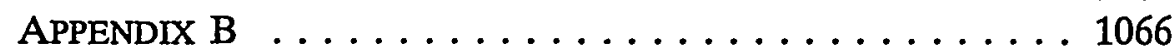

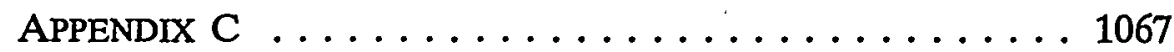

APPENDIX D ....................... 1068

$\dagger$ Copyright $\odot$ 1993, A. Leon Higginbotham, Jr.

Chief Judge Emeritus of the U.S. Court of Appeals for the Third Circuit; Senior Fellow, University of Pennsylvania Law School; Of Counsel, Paul, Weiss, Rifkind, Wharton \& Garrison. 
We point with pride to the election of one black man to public office or the appointment of one black woman to a position of responsibility in the private sector. That is hardly an expiation for all that has happened to deny equality of blacks for three hundred years, but we are tempted to believe that it is. Racial violence continues to stalk the land. Inequalities of infinite varieties and complexities persist. Racial injustice in housing, employment, and education pervades the nation. Their linkage to the sins of our fathers of the eighteenth and nineteenth centuries is clear. If they stumbled, groped, and fell-for whatever reasons-that was their misfortune, but it should not be ours. ${ }^{1}$

When John Hope Franklin wrote these words in 1976, it was in recognition that the bill which America had incurred through two hundred years of slavery and one hundred years of apartheid could never be paid in full with mere symbolic acceptance of a few blacks into institutions that remained forever white and forever racist. Today, most American institutions remain deeply nonpluralistic. In the federal judiciary, the small but significant gains toward pluralism which were achieved between 1948 and 1980, were systematically eroded and virtually eliminated during the Reagan and Bush presidential years. Sometimes it seems that as a nation we have decided that a few decades of racial progress in the judiciary can expiate for the sins of three hundred years of racial injustice. Similarly, the people of South Africa are only now beginning to confront the horrible legacy of their apartheid past in their society as a whole and in their judiciary. They are only now learning what we in America seem to have forgotten, that centuries of state-sponsored racial oppression cannot be remedied by token concessions. Until blacks are fully enfranchised, South Africa will remain a "white man's government" with little hope of becoming a true democracy, just as until American institutions commit themselves to pluralism, we will remain untrue to our own constitution with little hope for liberty and justice for all.

1. John H. Franklin, Racial Equality in America 74 (1976). For decades, John Hope Franklin has been my mentor. His writings and teachings have set the standard for perceptive analysis in history and law for the past half-century. No other scholar's contributions have been as insightful and timeless. I am delighted that this issue of the Duke Law Joumal is dedicated to a man whose work has played such a profound role in the ongoing search for human equality. 
Achieving racial pluralism in the power structures of both the United States and South Africa will present extraordinary challenges. Meaningful long-term results can only occur if there is a conscious, persistent and monitored commitment to pluralism in the public and private sectors. For, as John Hope Franklin taught us, we need to identify and attack the "infinite varieties and complexities" of racial and gender inequality wherever they may occur. I hope this Article in some small way can play a role in that process.

\section{INTRODUCTION ${ }^{2}$}

The Republic of South Africa and its citizens are struggling to abolish apartheid and to introduce democracy to that strife-laden nation. As Gay J. McDougal has perceptively observed:

2. This Article is a culmination of more than ten years of collaborative efforts with many academicians and lawyers, both in South Africa and in the United States. It started im 1982, when I was chairman of a delegation that visited South Africa at the request of the Black Lawyers of South Africa; others in that delegation were Julius L. Chambers, then President and Director of the NAACP Legal Defense Fund, Thelton E. Henderson, Chief Judge of the U.S. District Court for the Northern District of California, and Sarah W. Mitchell, Esq. This Article is a substantial revision of a paper prepared by A. Leon Higgimbotham, Jr. and S. Sandile Ngcobo, then an associate at Pepper, Hamilton \& Scheetz, Philadelphia, Pa., and now an advocate in Durban, South Africa. It was presented to the Conference on a Constitutional Court for South Africa, sponsored by the Constitutional Committee of the African National Congress (ANC), the Centre for Applied Legal Studies, University of the Witswatersrand, and the Lawyers' Committee for Civil Rights Under Law on February 1, 1991. The other judges who participated in this conference were: Chief Justice Bhagwathi of India; Justice Crabbe of Ghana and Barbados; Chief Justice Dumbutshena of Zimbabwe; Justice Eso of Nigeria; Chief Justice Lallah of Mauritius; and Justice Tarnopolsky of Canada.

I have done all of the analysis of the American experience, and Sandile Ngcobo and F. Michael Higginbotham have done some of the analysis of the South African cases. Since his return to South Africa, Sandile Ngcobo has not had the time to collaborate on the many revisions that have been made during the last two years and he may not agree with some of the substantial modifications and additions that have been made since the paper's original presentation. Michael Higginbothain and I are co-authoring a book, The Long Joumey to Freedom: The South African and American Legal Experiences, soon to be published, that deals more comprehensively with the similarities and differences between the South African and American legal processes.

I acknowledge the significant editorial assistance of Esperanza Anderson, J.D. 1991, Northeastern University School of Law; Mark R. Eskin, J.D. 1993, Temple University School of Law; Aderson Bellegarde Francois, J.D. 1991, New York University Law School; Marianne Hoffman, J.D. 1994, University of Pennsylvania School of Law; Jonathan Klaaren, J.D. 1991, Columbia University School of Law; Anita Jackson-Wieck, B.A. 1993, University of Pennsylvania; and Eric A. Tilles, J.D. 1989, University of Pennsylvania Law School. 
The task before [the South African government and opposition parties] is a weighty one. They must devise a constitutional formula that will facilitate fundamental change, that will be a vehicle to undo what decades of apartheid and centuries of racial oppression have wrought. Good governance is a minimum standard, but so much more will be demanded. ${ }^{3}$

Some of South Africa's many challenges ${ }^{4}$ will include the structuring of its constitution, ${ }^{5}$ the securing of fundamental human rights for all of its citizens, ${ }^{6}$ and a resolution as to what process it

3. Gay J. McDougal, RECORDER, July 28 , 1992, at 8. Ms. McDougal is Director of the South African Project of the Lawyers' Committee for Civil Rights Under Law, which assists South African leadership groups in planning for a democratic government. For more than thirteen years, she has been one of the most effective advocates of the United States' opposition to apartheid in South Africa and has helped to build broad-based support for the African National Congress and other organizations supporting the liberation of South Africa.

4. Many excellent books on South Africa are available. These include: JoHN W. CELl, THE HIGHEST STAGE OF WHITE SUPREMACY: THE ORIGINS OF SEGREGATION IN SOUTH AFRICA AND THE AMERICAN SOUTH (1982); DEMOCRATIC LIBERALISM IN SOUTH AFRICA: ITS HISTORY AND PROSPECT (Jeffrey Butler et al. eds., 1987); JOHN DUGARD, HUMAN RIGHTS AND THE SOUTH AFRICAN LEGAL ORPER (1978); JOHN DUGARD ET Al., THE Last Years of APARTHEID: Civil Liberties IN SOUTH Africa (1992); STEPHEN J. EllmanN, IN a Time of Trouble: LAW AND LIBERTY IN SOUTH AFrica's STATE OF EMERGENCY (1992); THE PRONTIER IN HISTORY: NORTH AMERICA AND SOUTHERN AFRICA COMPARED (Howard Lamar \& Leonard Thompson eds., 1981); STANLEY B. GREENBERG, RACE AND STATE IN CAPITALIST DEVELOPMENT: COMPARATIVE PERSPECTIVES (1980); MURIEL HORRELL, LAWS AFFECTING RACE RELATIONS IN SOUTH AFRICA 1948-1976 (1978); ROBERT S. JASTER ET AL., CHANGING FORTUNES: WAR, DIPLOMACY, AND ECONOMTCS IN SOUTHERN AFRICA (1992); FRANCES KENDALL \& LEON LOUW, AFTER APARTHEID: THE SOLUTION FOR SOUTH AFRICA (1987); JOSEPH LELYVELD, MOVE YOUR SHADOW: SOUTH AFRICA, BLACK AND WHTTE (1985); JANET LEVINE, INSIDE APARTHEID: ONE WOMAN'S STRUGGLE IN SOUTH AFRICA (1988); TOM LODGE \& BILl NASSON, ALl, HERE, AND NOW: BLACK POLITICS IN SOUTH AFRICA IN THE 1980S (1991); ANTHONY S. MATHEWS, FREEDOM, STATE SECURTTY AND THE RULE OF LAW: DILEMMAS OF THE APARTHEID SOCIETY (1986); MARTIN MEREDITH, IN THE NAME OF APARTHEID: SOUTH AFRICA IN THE POST WAR PERIOD (1988); RACE AND THE LAW IN SOUTH AFRICA (A.J. Rycroft et al. eds., 1987); RACE DISCRIMINATION IN SOUTH AFRICA: A REVIEW (Sheila T. van der Horst ed., 1981); ALBIE SACHS, JUSTICE IN SOUTH AFrica (1973); ROBERT A. SCHRIRE, ADAPT OR DIE: THE END OF WhITE POLITICS IN SOUTH AFRICA (1991); SOUTH AFRICA: No TURNING BACK (S. Johnson ed., 1989); LEONARD M. THOMPSON, THE POLITICAL MYTHOLOGY OF APARTHEID (1985); FRANCIS WILSON \& MAMPHELA RAMPHELE, UPROOTING POVERTY: THE SOUTH AFRICAN CHALlENGe (1989).

5. See, e.g., Panel Discussion, Constitutional Developments in Souther Africa, 85 AM. SOC'Y INT'L L. PROC. 303 (1991); Charles Villa-Vicencio, Whither South Africa?: Constitutionalism and Law-Making, 40 EMORY L.J. 141 (1991); Johan D. van der Vyver, Constitutional Options for Post-Apartheid South Africa, 40 EMORY L.J. 745 (1991).

6. See, e.g., David Dyzenhaus, Democracy, Rights, and the Law, 7 S. AFr. J. ON 
will adopt to guarantee racial and gender pluralism in its governmental and judicial systems. As South Africa confronts the challenge to incorporate pluralism into its judicial system, the United States' experience of judicial pluralism in the federal courts is a relevant topic for inquiry and comparison. ${ }^{7}$

This Article first explores the public perception problems of an unrepresentative judiciary. Part I discusses both the public's perception of an unrepresentative judiciary and the unrepresentative judiciary's problem of perception of the public. Part II sets forth some outgrowths of public perception problems in the judicial systems of the United States and South Africa. However, these problems are not without solutions. Thus, Part III looks at the United States' experience in building a more pluralistic and representative judicial system. The discussion of both the success and failure of this experience proceeds with an eye toward its relevance for South Africa, which is taken up in Part IV. Finally, the Article closes with some thoughts on the interrelationship of the challenges of creating a viable, fair, and pluralistic constitutional court and an effective bill of rights in South Africa.

Whether one studies the United States or South Africa, it soon becomes evident that any nation that seeks to structure a fair, pluralistic judicial system must do more than merely remove the vestiges of past racism $^{8}$ in order to establish the best values and qualities of an effective judicial system. ${ }^{9}$ Although this Article

HUM. RTS. 24 (1991); Christopher Forsyth, Interpreting a Bill of Rights: The Future Task of a Reformed Judiciary?, 7 S. AFR. J. ON HUM. RTS. 1 (1991); Nicholas Haysom, Democracy, Constitutionalism and the ANC's Bill of Rights for a New South Africa, 7 S. AFR. J. ON HUM. RTS. 102 (1991); M.C. Lozana, Proposed South African Bill of Rights: A Prescription for Equality or Neo-Apartheid, 7 AM. U.J. INT'L L. \& POL'Y 45 (1991); Craig Scott \& Patrick Macklem, Constitutional Ropes of Sand or Justifiable Guarantees? Social Rights in a New South African Constitution, 141 U. PA. L. REV. 1 (1992); see also Melissa Cole, Inthuthuko Means that We Are Going Forward, 2 COLUM. J. GENDER \& L. 61 (1992); Adrien K. Wing, Communitarianism vs. Individualism: Constitutionalism in Namibia and South Africa, 11 WIS. J. INT'L L. (forthcoming 1993).

7. I focus in this Article on the nomination rather than the confirmation process. For some insights on the present confirmation process, see PAUL SIMON, ADVICE \& CONSENT: CLARENCE THOMAS, ROBERT BORK AND THE INTRIGUING HISTORY OF THE SUPREME COURT'S NOMNATION BATTLES (1992); LAURENCE H. TRIBE, GOD SAVE ThIS HoNorable COURT: How tHe CHOICE OF SUPREME COURT JUSTICES CAN Change OUR LIVES (1985); David A. Strauss \& Cass R. Sunstein, The Senate, The Constitution, and the Confirmation Process, 101 YALE L.J. 1491 (1992).

8. Particularly for any nation that docs not have a longstanding tradition guaranteeing fundamental human rights for all, it is essential that its court system have a viable, equitable, and enforceable bill of rights.

9. See generally Ruggero J. Aldisert, The Judicial Process: REAdings, MATE- 
does not focus on any major issues other than pluralism, I want to make clear that pluralism constitutes only one of the many complex elements involved in creating a viable judicial system. The present and future policymakers of South Africa must explore and resolve many elements other than pluralism. Even if a court system is integrated by both race and gender, in the long run it will not and should not satisfy citizens unless it is also efficient, principled, and responsible with regard to all aspects of the judicial process. As Chief Justice Earl Warren noted some decades ago:

The orderly and expeditious processing of litigation is a right which each of us should be able to ask of our judicial system ... yet we must admit that we are falling far short of our goal.... [W]e have paid little attention to the practical problems of the administration of justice.... Our efforts must be on a much larger scale, with massive support on the part of all of us if we are to meet the challenge. ${ }^{10}$

\section{The Public Perception Problems of aN UNREPRESENTATIVE JÜDICIARY}

Some people might ask what is wrong in having an unrepresentative judiciary. They might even suggest that the best judiciary is one that is not even close to being truly representative of a nation, that is not remotely representative of the nation's present lawyer population, and that is not proportionately representative of the major racial, religious, national origin, and ethnic groups among the nation's citizens.

It is my suspicion that those groups that are the most tolerant of an unrepresentative judiciary are composed of individuals who have been the major beneficiaries of a judicial system that is not pluralistic in its composition. ${ }^{11}$ They are quite content with the

rials and Cases (1976); Dorothy W. Nelson, Cases and Materials on Judicial ADMINISTRATION AND THE ADMINISTRATION OF JUSTICE (1974); Ruggero J. Aldisert, Rambling Through Continental Legal Systems, 43 U. PrTT. L. REV, 935 (1982).

10. Chief Justice Earl Warren, Address at Harvard Law School (Sept. 23, 1967), quoted in NELSON, supra note 9, at XIV (omissions in original). For analyses of the administrative operations experiences of the federal courts, see the annual reports of the Director of the Administrative Office of the United States Courts and the annual reports of the Federal Judicial Center.

11. As an example, most Americans seem oblivious to or are unconcerned about the fact that Presidents Reagan and Bush have appointed so few blacks to the federal judiciary. See A. Leon Higginbotham, Jr., The Case of the Missing Black Judges, N.Y. TiMES, 
system as long as their "group" enjoys a more advantageous position than would have been possible had the judges been more proportionately representative of the population. ${ }^{12}$ An unrepre-

July 29, 1992, at A21 (asking "[h]ow it is that in President F.W. de Klerk's less than three years in office, one of his 31 appointments to South Africa's courts is a black lawyer while of the 115 Bush and Reagan appointments to the Court of Appeals in 12 years, only two have been African-American?"). The public sees nothing wrong with the disproportionate underrepresentation of blacks within the judiciary, and it never considers the consequences of the racial overrepresentation of blacks in the armed services and in the ranks of the poor. A New York Times editorial of January 28, 1991 noted:

Close to 30 percent of the Army's troops in Operation Desert Storm are black, though blacks are just 14 percent of the nation's population between the ages of 18 and 24. In a land war, black casualties will be similarly disproportionate. Is it fair? Is it inevitable? For answers, one inust search the soul of American society.

$$
\text { .... }
$$

.. . Almost 21 percent of U.S. forces worldwide are black; the figure is higher in the gulf because of large Army and Marine contingents.

Clifford Alexander, a black who was Secretary of the Army in the 1970's, explained the imbalance at the time in a few pointed words: "[Ask] why there is almost $\mathbf{4 0}$ percent unemployment ainong black teen-agers before you ask why they enlist or why they re-up." Their jobless rate is still above 30 percent, and the point endures: the military offers blacks more opportunities than life on the outside.

The Killing Fields, Aren't Level, N.Y. TiMES, Jan. 28, 1991, at A2.

Similarly, the Wall Street Joumal on January 25, 1991 noted:

A new nationwide Wall Street Journal/NBC News poll shows that a majority of black voters support President Bush and the U.S. decision to go to war in the Persian Gulf, for inost of the reasons that white voters do. Yet a much higher percentage of black voters are skeptical of the war effort than are white voters. While $78 \%$ of white voters surveyed this week said the president had waited long enough before using military force, only $52 \%$ of black voters agreed; twice as many blacks as whites- $39 \%$ vs. $19 \%$-thought Mr. Bush should have given sanctions more time to work.

$$
\text { .... }
$$

... [T] The split in the black community doesn't fit neatly into age groups or socioeconomic categories. While some successful black businessmen support the war, for instance, others oppose it. Thounas Hightower, a businessman in Burbank, Calif., says, "It's not about civil rights, but about oil. And look who's at the heart of the decision-making process: wealthy white males who are sending uninorities to their death."

Suzanne Alexander et al., Guns v. Butter: Many Blacks Oppose America's Role in War Citing Domestic Needs, WALL ST. J., Jan. 25, 1991, at A1, A7.

12. Such a belief was poignantly revealed to me in a racial discrimination suit tried before me nearly twenty years ago. See Pennsylvania v. Local Union 542, Int'l Union of Operating Engineers, 388 F. Supp. 155 (E.D. Pa. 1974). In this suit, the predoininantly white labor union, as defendant, challenged my competency to render an impartial decision in the case because of my race, my reputation as a scholar in the field of race relations, and iny participation in an annual meeting of historians studying Afro-American life and history. Because the defendant's counsel and his firm had in the past tried several cases before me in which the litigants were not of the same race without challenging any impartiality, it is difficult to believe that the request to have me removed from the case was based upon a belief that they would not be able to get a fair and just decision 
sentative judiciary, however, affects both the public's perception of the judiciary and the judiciary's perception of the public.

\section{A. The Public's Perception of the Judiciary}

To put the issue of unrepresentativeness in perspective, one must recognize that there are vast differences among (1) a judicial system that is completely exclusionary, (2) a system that is so homogeneous that it is de facto unrepresentative, and (3) a system that is at least partially pluralistic. The United States federal courts $^{13}$ until 1949, and the major courts of present South Africa, at least until 1991, could be categorized as both exclusionary and racially homogenous. The United States federal courts ${ }^{14}$ were de facto racially exclusionary from 1789 to $1949 .{ }^{15}$ From 1949 to

from me.

13. For persons not familiar with our judicial system, I note that there are primarily two different court systems in the United States. One is the separate judicial system in each of the 50 states, and the other is the federal court system. For a discussion of the creation of the federal courts, see RUSSELI R. WHEELER \& CYNTHIA HARRISON, CREATING THE FEDERAL JUDICIAL SYSTEM (1989).

14. My comments are addressed only to the federal court system of the United States. Representativeness, however, has been an issue in the state courts also. See Barbara L. Graham, Judicial Recruitment and Racial Diversity on State Courts: An Overview, 74 JUDICATURE 28, 34 (1990) (concluding that "although black attorneys have made significant gains on the state bench since the 1970s, black underrepresentation still remains a problem").

15. When I speak of federal courts in this Article, I refer only to the Article III courts of record. In the territorial courts, however, William Henry Hastie was appointed in 1937. See GIlberT WARE, William Hastie: Grace UNDER PREsSURE 85-86 (1984). From 1789 to at least 1868, of course, the federal courts were also de jure racially exclusionary, as blacks had no rights as citizens of the United States until the enactment of the Fourteenth Ainendment in 1868.

As to the "lower" federal courts, in 1890, President Benjamin Harrison appointed Emanuel M. Hewlett to the position of Justice of the Peace in the District of Columbia. He was the second black federal "judge." M. Sammy Miller, Robert Heberton Terrell, 1857-1925: Black Lawyer and Community Leader (1977) (unpublished Ph.D. dissertation, Catholic University of America). But as a Justice of the Peace, Hewlett had very limited jurisdiction, presiding over a court known as the "Poor Man's Court." Id. at 117.

In 1901, President Theodore Roosevelt nominated, and the Senate confirmed, Robert $\mathrm{H}$. Terrell to join Hewlett as a justice of the peace. Id. at 116. Terrell was the first African-American to graduate cum laude from Harvard College and attended Howard University Law School. Id. at 111. By all accounts, he was recognized as an intelligent man.

In 1909, Congress eliminated the position of Justice of the Peace in the District of Columbia and created a new system of municipal courts for the District. These courts had jurisdiction over claims under $\$ 500$. Id. at 117 . 
1980 , the federal judiciary was characterized by a slowly evolving racial pluralism. ${ }^{16}$ Then, from 1980 to 1992 , because of the policies of Presidents Reagan and Bush, there was a marked decline in the percentage of blacks appointed to the federal courts and thus a decrease in pluralism. ${ }^{17}$

Some persons might argue that it is possible to have a viable, fair, and effective judicial system even when there is no significant statistical correlation between the composition of the court and the nation's population. Nevertheless, I submit that it is difficult to have a court that in the long run has the respect of most segments of the public if it has no pluralistic strands in its composition. Although the values held by each individual judge are important, and although mere pluralism does not guarantee an effective court, pluralism is nevertheless an important virtue, a sine qua non to building a court that is both substantively excellent and also respected by the general population. More often than not, judicial homogeneity and exclusivity are deterrents to, rather than promoters of, equal justice for all. As Justice Benjamin Cardozo has advised us:

We do not pick our rules of law full-blossomed from the trees. Every judge consulting his own experience must be conscious of times when a free exercise of will, directed of set purpose to the furtherance of the common good, determined the form and tendency of a rule which at that moment took its origin in one creative act. ${ }^{18}$

Terrell faced a serious battle in his bid to be reappointed to the Municipal Court in 1914. The exclusively white District Bar Association urged the recently-elected President, Woodrow Wilson, to reappoint Terrell on the grounds that he was the best judge ever to have sat on the Municipal Court. Id. at 149. Wilson did nominate Terrell, and after a bruising confirmation battle, the Senate reappointed Terrell by a vote of 39-24 on April 24, 1914. Id. at 157.

During the presidential election of 1916, the so-called Progressive Party used Judge Terrell's reappointment to draw votes away from Wilson. For example, in one political cartoon from that time, Judge Terrell is portrayed with the usual big, bulging white eyes and large red lips. He is heard to say from the bench: "Dis cote come to order, you white folks stan' up an' recieve [sic] yo' sentence!" This cartoon is reprinted in id. at 171.

Of course, Judge Terrell was nothing like the incompetent Sambo depicted in that cartoon. Harvard University may not be all that its graduates think it is, but it docs require a great deal of talent to graduate cum laude from Harvard, especially for a black man living in the late 1800 s.

16. See infra notes $91-98$ and accompanying text.

17. See infra notes $97-98$ and accompanying text.

18. Benjamin N. Cardozo, The Nature of the Judicial Process 103-04 (1921). 
I do not want to be misunderstood. Pluralism does not mean that only a judge of the same race as a litigant will be able to adjudicate a case fairly. A discussion on pluralism is not grounded on a premise that a judge of a specific race, religion, gender, or region is able to decide a case more fairly than a judge of another race, religion, ethnic background, gender, or region. ${ }^{19}$ Instead, I am suggesting that pluralism creates a milieu in which the entire judicial system benefits from multi-faceted experiences with individuals who come from different backgrounds. ${ }^{20}$

(emphasis added).

19. Similarly, I am not suggesting that all persons of the same racial, religious, or ethnic background share a monolithic view of every issue. There is almost as much difference between the views of Justice Thurgood Marshall, the first African-American to serve on the U.S. Supreme Court, and Justice Clarence Thomas, the second AfricanAmerican to hold that honor, as there is between what mathematicians would call the difference between infmity and zero. However, I submit that Justice Thomas, as a constructed clone of the Reagan/Bush racial views, was and is aberrational for African-Americans as to his views on race. See generally A. Leon Higginbotham, Jr., An Open Letter to Justice Clarence Thomas from a Federal Judicial Colleague, 140 U. PA. L. REV. 1005, 1012-20 (1992) (comparing the views of Clarence Thomas with those of other AfricanAmericans); see also RACE-ING JUSTICE, EN-GENDERING POWER: ESSAYS ON ANITA Hill, Clarence Thomas, and the Construction of Social RealtTy (Toni Morrison ed., 1992).

20. In a somewhat different context, in support of salary increases for the federal judiciary, I testified on January 31, 1989 before the Governmental Affairs Committee of the U.S. Senate. At that time, I expressed some thoughts on pluralism:

I use the term "pluralism," rather than "diversity" because the definition of pluralism more completely characterizes the manner by which, ideally, our federal judiciary should be constituted: that is, reflective of many points along the spectrum and not merely a few different points or even merely the extremes.

Of course, judges vote and adjudicate as independent persons. They are not representatives for any specific constituency. They must strive always to be impartial and fair. Because of the many interstitial zones in the adjudicative process, however, where there is no clear controlling precedent, or sufficient specific legislative direction, it is impossible to eliminate the impact of one's experience.

... With our present judicial salary scale, our judiciary faces a difficult future if we desire to continue the pluralism and competence that exemplifies the present judges on the United States Court of Appeals for the Third Circuit, [and] the Judges on the U.S. District Court for the Eastern District of Pennsylvania .... The greatness of these courts is that they have not been dominated by any monolithic type or background. They have not been a collection of identical clones. They were not dominated solely by lawyers who had accumulated vast wealth, either through law practice, inheritance, or marriage. They are not dommated by former state judges. They are not dominated by idealogues. Instead, they were composed of some lawyers who had extraordinary careers in the public sector or with small law firms, and some tremendously capable lawyers who had accumulated relatively very few assets, and some lawyers from the big firms' lucrative practices, and some lawyers with state court experience. There are some who were born into extraordinary wealth, and others who had endured poverty and racism in their youth. The goal of achieving federal courts 
I submit that whether in the United States or in South Africa, the perceived or actual partiality of judges causes those racial groups not represented in the judiciary to have less confidence in the courts. When all the judges come from the ranks of the ruling race, they often are viewed more as representatives or advocates for the ruling race than as judges committed to an impartial rule of law. When the public perceives the judiciary as having a vested interest in the preservation of the status quo, victims of racism or gender discrimination or poverty often wonder whether the jurist is putting a thuinb on the scales of justice to make sure the system denies them full dignity.

Dr. Nelson Mandela, when challenging the right of a white South African court to sit in judgment over a case involving the violation of human rights of blacks by the white government, argued:

The White man makes all the laws, he drags us before his courts and accuses us, and he sits in judgment over us.

It is fit and proper to raise the question sharply, what is this rigid colour-bar in the administration of justice? Why is it that in this courtroom I face a White magistrate, confronted by a White prosecutor, and escorted into the dock by a White orderly? Can anyone honestly and seriously suggest that in this type of atmosphere the scales of justice are evenly balanced?

Why is it that no African in the history of this country has ever had the honour of being tried by his own kith and kin, by his own flesh and blood? 21 $^{2}$

In response to charges of judicial bias, some judges are quite candid in expressing their partisanship and their concern over any conduct that threatens the status quo. The judge hearing Mandela's case, Justice Bekker, in responding to Mandela's deinand for freedom, asked rhetorically, "Well, as a matter of fact, isn't your freedoin a direct threat to the Europeans?"22 Com-

with such pluralism and breadth in the future is made much more difficult by a salary that falls significantly behind the needs of many of the individuals that we desire to attract.

Report of 1989 Commission on Executive, Legislative, and Judicial Salaries: Hearings Before the Senate Committee on Governmental Affairs, 101st Cong., 1st Sess. 146, 163 n.19, 164 (1989) (prepared statement of A. Leon Higginbotham, Jr., Circuit Judge, U.S. Court of Appeals for the Third Circuit).

21. Nelson mandela, No Easy walk to Freedom 127 (1965).

22. Id. at 83. 
ments such as these demonstrate support for the status quo and make the oppressed skeptical of the judicial system. ${ }^{23}$

The lay black community has often voiced its lack of confidence in the South African bench. Three cases involving whites accused of murdering blacks were tried in Volksrust in March and April of $1984 .{ }^{24}$ In two of the cases, the defendants were white policemen; in a third, a white farmer had shot a black victim, ostensibly by accident. ${ }^{25}$ In all three cases, the white defendants were acquitted.

After witnessing these three trials, black residents of Driefontein remarked: "We can be shot down like birds in the sky.' 'We want a judge from overseas to come and hear this trial again." "26 The request for a "judge from overseas" reflects a perception that the white judiciary of South Africa is so intertwined with the apartheid society of South Africa that it cannot make impartial findings of fact.

Statements of the white-dominated bar associations condemning light sentences imposed on whites convicted of killing blacks support the black community's perception of South African judges' partiality. Recently, the Johannesburg Bar issued a formal condemnation of Justice J.J. Strydom for sentencing a white farmer found guilty of killing a black farm laborer to five years in prison and

23. For a collection of American cases in which white judges have expressed similar antagonism, see A. Leon Higginbotham, Jr., Racism in American and South African Courts: Similarities and Differences, 65 N.Y.U. L. REv. 479, 521-50 (1990).

An example of conscious judicial indifference to unrepresentativeness in South Africa was revealed in an adjudication regarding the Group Areas Act, under which hundreds of thousands of black South Africans were removed from their homes:

The Group Areas Act represents a colossal social experiment and a long term policy. It necessarily involves the movement out of Group Areas of numbers of people throughout the country. Parliament must have envisaged that compulsory population shifts of persons occupying certain areas would inevitably cause disruption, and withm the foreseeable future, substantial inequalities. Whether all this will ultimately prove to be for the common weal of all the inhabitants is not for the Court to decide.

Mimister of the Interior v. Lockhat, 1961(2) S.A. 587, 602 (App. Div.) (Holmes, J.A.).

24. See Nicholas Haysom, Law and Order in the Eastem Transvaal, LAW. FOR HUM. RTS. BULL. 44, 44-54 (1984).

25. This third case involved a white farmer who killed a Mr. Mavimbela for allegedly trespassing over the farmer's property line on horseback. The farmer pleaded that he shot the horse dead and then stumbled, accidentally shooting Mr. Mavimbela. Id. at 49. The farmer was acquitted of all the charges and was not even convicted of any lesser offense. Id.

26. Haysom, supra note 24, at 44 (quoting Driefontein community residents following the trials). 
then suspending the sentence on the condition that the farmer pay a fine to the court of approximately R1,260 and damages to the deceased's widow of approximately R55 per month for five years. ${ }^{27}$ As punishment for running over his two dogs with a tractor, the white farmer had tied the black laborer to a tree and beaten him to death over the course of two days. ${ }^{28}$

B. The Judiciary's Problem of Perception of the Public, or "The Prejudices Judges Share with Their Fellow Men"

Although unintentionally, perhaps no one has put the representation issue in better perspective than Justice Oliver Wendell Holmes. In his famed lectures at Harvard more than a century ago, which became his landmark treatise, The Common Law, Justice Holmes framed the problem as follows:

The life of the law has not been logic: it has been experience. The felt necessities of the time, the prevalent moral and political theories, intuitions of public policy, avowed or unconscious, even the prejudices which judges share with their fellow-men, have had a good deal more to do than the syllogism in determining the rules by which men should be governed. ${ }^{29}$

In another context, Professor Charles Warren categorized the problem this way:

The Court is not an organism dissociated from the conditions and history of the times in which it exists. It does not formulate and deliver its opinions in a legal vacuum. Its Judges are not abstract and impersonal oracles, but are men whose views are necessarily, though by no conscious intent, affected by inheritance, education and environment and by the impact of history past and present .... .30

As Holmes and Warren pointed out, one aspect of the problem of a vastly unrepresentative or exclusionary judiciary is that those in control often articulate precepts or rules of law that seem to them to be basically fair. They never even imagine that their

27. Christopher S. Wren, Johannesburg Lawyers Condemn a Judge's Ruling, N.Y. TIMES, Jan. 28, 1989, at A28.

28. $I d$.

29. OlJVER W. HOLMES, JR., THE COMMON LAW 1 (1881) (emphasis added). (1926).

30. 1 Charles Warren, THE SUPREME COURT IN UNITEd STATES History 2 
views are nothing more than the "prejudices" they "share with [some of] their fellow men." In articulating these precepts, these judges are sometimes insensitive to the injustice their decisions cause, or are likely to cause, their victims. The American and the South African experiences ${ }^{31}$ are replete with examples of such judicial biases. ${ }^{32}$

To some degree, these prejudices serve to reinforce the public's lack of confidence in the judicial system. A racially unrepresentative judiciary is seen as an instrument for imposing the will of the ruling race on other racial groups. Therefore, partiality, experienced or perceived, and lack of public confidence in the bench often characterize an unrepresentative or exclusionary bench.

To a significant degree, partiality and even unrecognized prejudices manifest a grave problem with an unrepresentative judiciary. The danger of a homogeneous court is that there is no "outsider" within the court to challenge the biases the dominant group accepts as "self-evident" truths. ${ }^{33}$ As Justice Sandra Day O'Connor, the first woman on the U.S. Supreme Court, has recently written of Justice Thurgood Marshall, the first black on the Supreme Court:

At oral arguments and conference meetings, in opinions and dissents, Justice Marshall imparted not only his legal acumen but also his life experiences, pushing and prodding us to respond not only to the persuasiveness of legal argument but also to the power of moral truth. ${ }^{34}$

31. The American experience is documented in Higginbotham, supra note 23.

32. Id. at 587 n.526. Some of the cases cited in the text of this Article are also discussed in my article, supra note 23. For more general discussion, see HUGH CORDER, JUDGES AT WORK: THE ROLE AND ATTTUDDES OF THE SOUTH AFRICAN APPELLATE JUDICIARY (1984); DUGGARD ET AL, supra note 4, at 95-111; RACE AND THE LAW IN SOUTH AFRICA, supra note 3, at 55-90; SACHs, supra note 4.

33. Of course, making a court plurahistic does not always mean that a "minority" or "majority" member will convey to that court the basic perception of a particular group. There will always be some persons of any racial, ethnic, or religious group who so favor assimilation that they accept or become oblivious to the racial, gender, or ethnic prejudices of their colleagues. These persons often criticize leaders of their own group to prove to those in power that they are assimilated and do not share the interests of others of their race, ethnic group, or religion. See Higginbotham, supra note 19, at 1011-14.

34. Sandra Day O'Connor, The Story Behind the Storyteller Thurgood Marshall, PHILADELPHIA INQUIRER, July 5, 1992, at E7; [hereinafter O'Connor, Story]; see also Sandra Day O'Connor, Thurgood Marshall: The Influence of a Raconteur, 44 STAN. L. REV. 1217 (1992). 
Justice O'Connor concluded that the stories of such outsiders "made clear what legal briefs often obscure: the impact of legal rules on human lives." 35 Lacking such outsiders, a court will be left with only its own self-perpetuating views, preferences, or prejudices to inform its decisions.

\section{The Outgrowths of Prejudice IN the Judicial Systems OF THE UNITED STATES AND SOUTH AFRICA}

Specific judicial manifestations of these prejudices take several forms. In some instances, these prejudices are both readily apparent and form the crucial policy determinant in the ultimate holding in a judicial decision. My recent survey of judicial decisions in the U.S. and South African courts demonstrates that many of the decisions can be explained solely by the prejudices of a racially unrepresentative bench. ${ }^{36}$ Segregation cases such as Moller $v$. Kiemoes School Committe $e^{37}$ in South Africa and Dred Scott $v$. Sandford ${ }^{38}$ in the United States are textbook examples of judicial prejudice manifest in judicial decisions.

The insensitivity of an unrepresentative court often becomes obvious in the manner in which judges characterize the issues before them and in the manner in which they resolve those issues. Many judges or lawyers are quick to justify their decisions by claiming that they are faced with difficult "legal questions," when in fact their ultimate decisions can be explained only as manifestations of unmistakably racial and other prejudices. ${ }^{39}$ A careful reading of many of the opinions suggests that the judges who rendered those decisions preferred perpetuating rather than eradicating racial discrimination.

The observation that the rules by which people are governed include the prejudices that judges share with their fellow human beings is especially true in a country where racism is institutionalized and where judges are trained in such an environment. ${ }^{40}$ It is

35. O'Connor, Story, supra note 34, at E7.

36. See generally Higginbotham, supra note 23 , at 502-50.

37. 1911 A.D. 635 (S. Afr. App. Div.).

38. 60 U.S. (19 How.) 393 (1856).

39. I have discussed this issue in greater detail in Higginbotham, supra note 23; see also supra text accompanying notes $37-38$.

40. As I have discussed this issue so extensively in earlier articles, I do not feel it necessary to revisit here ground I have previously covered. See, e.g., Higginbotham, supra 
evident that there have been innumerable instances of explicit judicial racism in both American and South African courts. American appellate courts, for example, have upheld convictions despite prosecutors' references to black defendants and witnesses in such racist terms as "black rascal,"41 "burr-headed nigger,"42 "big nigger,"43 "pickaninny,"44 "mean nigger,"45 "three nigger men,"46 and "nothing but just a common negro, [a] black whore." ${ }^{, 47}$ Similarly, the South African case of Moller $v$. Kiemoes School Committee ${ }^{48}$ represents an explicit judicial statement that the racial prejudices of the white community will be taken into consideration in deciding the rights of black people. In Moller, the highest tribunal in the land stated:

As a matter of public history we know that the first civilized legislators in South Africa came from Holland and regarded the aboriginal natives of the country as belonging to an inferior race, whom the Dutch, as Europeans, were entitled to rule over, and whom they refused to admit to social or political equality. We know also that, while slavery existed, the slaves were blacks and that their descendants, who form a large proportion of the coloured races of South Africa, were never admitted to social equality with the so called whites .... These prepossessions, or, as many might term them, these prejudices, have never died out, and are not less deeply rooted at the present day among the Europeans in South Africa, whether of Dutch or English or French descent. We may not from a philosophical or humanitarian point of view be able to approve this prevalent sentiment, but we cannot, as judges, who are called upon to construe an Act of Parliament, ignore the reasons which must have induced the

note 23. Moreover, given my ultimate focus on working to recast the South African judicial system, I think it useful to point out that Justice Holmes's statement about prejudices judges share with their fellow men, supra text accompanying note 29 , itself derived from and instructive for the Anerican context, applies with equal analytic force in the South African context.

41. State v. Miles, 98 S.W. 25, 31 (Mo. 1906).

42. Adams v. State, 216 S.W. 863, 864 (Tex. Crim. App. 1919).

43. State v. Hubbard, 195 P.2d 604, 605 (Kan. 1948).

44. People v. Curry, 218 P.2d 153, 161 (Cal. Dist. Ct. App. 1950).

45. Quarles v. Commonwealth, 245 S.W.2d 947, 949 (Ky. Ct. App. 1951).

46. Thornton v. State, 451 S.W.2d 898, 903 (Tex. Crim. App. 1970).

47. Hilson v. State, 258 S.W. 826, 826 (Tex. Crim. App. 1924).

48. 1911 A.D. 635 (S. Afr. App. Div.). 
legislature to adopt the policy of separate education for European and non-European children. ${ }^{49}$

There is a striking similarity between the language and reasoning of Moller and the opinions of the U.S. Supreme Court in Dred Scott v. Sandford ${ }^{50}$ and Plessy v. Ferguson..$^{51}$ These cases demonstrate that many judges are inclined to affirm the prejudices of their own racial group to the detriment of unrepresented racial groups.

This bias becomes apparent when judges have to make value judgments or exercise so-called judicial discretion. In the South African case of Minister of Posts and Telegraphs $v$. Rasool, ${ }^{52}$ the Appellate Division was required to decide, inter alia, whether

49. Id. at 643-44.

50. 60 U.S. (19 How.) 393 (1856). Chief Justice Taney wrote:

In the opinion of the court, the legislation and histories of the times, and the language used in the Declaration of Independence, show, that neither the class of persons who had been imported as slaves, nor their descendants, whether they have become free or not, were then acknowledged as a part of the people, nor intended to be mcluded in the general words used in that memorable instrument.

It is difficult at this day to realize the state of public opinion in relation to that unfortunate race, which prevailed in the civilized and enlightened portions of the world at the time of the Declaration of Independence, and when the Constitution of the United States was framed and adopted. But the public history of every European nation displays it in a manner too plain to be mistaken.

They had for more than a century before been regarded as beings of an inferior order, and altogether unfit to associate with the white race, either in social or political relations; and so far inferior, that they had no rights which the white man was bound to respect; and that the negro might justly and lawfully be reduced to slavery for his benefit. He was bought and sold, and treated as an ordinary article of merchandise and traffic, whenever a profit could be made by it. This opinion was at that time fixed and universal in the civilized portion of the white race. It was regarded as an axion in morals as well as in politics, which no one thought of disputing, or supposed to be open to dispute; and men in every grade and position in society daily and habitually acted upon it in their private pursuits, as well as in matters of public concern, without doubting for a moment the correctness of this opinion.

Id. at 407.

51. 163 U.S. 537 (1896). In upholding Louisiana's statute requiring the separation of the races in passenger train coaches, the Court reasoned:

[1]n determining the question of reasonableness [the legislature] is at liberty to act with reference to the established usages, customs and traditions of the people, and with a view to the promotion of their comfort, and the preservation of the public peace and good order. Gauged by this standard, we cannot say that a law which authorizes or even requires the separation of the two races in public conveyances is unreasonable, or ... obnoxious to the Fourteenth Amendment.

Id. at 550-51.

52. 1934 A.D. 167 (S. Afr. App. Div.). 
requiring the Indian community to use the same post office counter as the African community (as opposed to the counter used by the white community, where Indians previously conducted their business) was reasonable. Not surprisingly, the court could find nothing unreasonable in a post office instruction requiring such segregation. The court found that such segregation was for the "convenience" and "comfort" of the races. ${ }^{53}$ From the facts of the case it is clear that the "convenience" and the "comfort" the court had in mind was that of the whites who had objected to being served at the same counter with Indians, and not the "convenience" and "comfort" of either the African or Indian communities. $^{54}$

Another example of the exercise of judicial discretion comes in the area of sentencing. As in the United States, the sentences handed out by a South African court can easily reflect the racial prejudices of the judicial system. One such sentence came in a case involving four policemen charged with culpable homicide and assault of one Absalom Manana and his son, Temba Manana. ${ }^{55}$ On this occasion, the judge did not have to choose between two conflicting versions of the facts; the police admitted that they had tortured the two black men by means of electric shocks and suffocation by hooding. ${ }^{56}$ Temba Manana had been found dead in his cell sometime after being tortured. ${ }^{57}$ Evidence was presented to establish that he had died of asphyxiation, probably caused by electrocution..$^{58}$ The policemen pled guilty to the charges but stated that they had not intended to seriously injure Temba Manana. ${ }^{59}$ They were acquitted of culpable homicide on the grounds that they could not have foreseen that Manana would die as a result of their torture, and were instead found guilty of assault. ${ }^{60}$ All four policemen were given suspended prison sentences and fines. ${ }^{61}$ The willingness of the judge in that case to give every imaginable benefit of the doubt to the feeble excuses present-
53. Id. at 175 .
54. Id. at $171-72$.
55. See Haysom, supra note 24 , at 49 .
56. Id. at $49-50$.
57. Id. at 50 .
58. Id.
59. Id.
60. Id.
61. Id. 
ed by the white defendants stands in stark contrast to the treatment that black witnesses received in another trial, concerning the killing of Saul Mkize. ${ }^{62}$ Had the victims been white police asphyxiated by blacks, it is hard to imagine that the blacks would not have been convicted of murder and then hanged from the gallows.

Sometimes judicial decisions reflect such prejudice and partiality even when the question at issue is not so much a matter of substantive policy as it is one of judicial procedure. For example, when deciding matters of credibility, judges are often called upon to choose among conflicting versions of events. Racial prejudice often manifests itself in those choices. A recent case involved the police killing of Saul Mkize, an elected leader of the Driefontein community, ${ }^{63}$ In the trial of a white policeman accused of the Mkize murder, the same judge presiding over the trial of the Mananas $^{64}$ acquitted the policeman, accepting his uncorroborated version of events over that of the black residents of Driefontein. ${ }^{65}$ Such prejudices are literally deadly, as a routine presumption that whites are more credible than blacks protects the organs of force of the state, largely controlled by whites, from accountability. ${ }^{66}$

The racist mythology that judges share with their racial groups is also apparent when judges are called upon to determine the amount of damages payable to a successful plaintiff. In a very candid statement, one judge said:

[I]n the case of a native, as is the plaintiff, who is earning the sum of $£ 2$ per week, I should most certainly not award the same amount for pain and suffering as I would for the same pain and suffering of a person who had more culture and, for instance, I would award a larger sum for damages in the case of an injury to a European woman than I would do for a native male, and so too, in the present case, if it had been a European of some

62. See infra text accompanying notes $63-65$.

63. Haysom, supra note 24 , at 44.

64. See supra text accompanying notes 55-61.

65. Haysom, supra note 24 , at $45-47$.

66. These prejudices also suggest, in a public forum, that in crimimal cases the state values black lives less than white lives-an important reinforcement for the general lesson of apartheid. In the companion civil suit (involving the same facts) filed against the police for negligence in the death of Saul Mkize, on the first day of trial the state settled by paying the full amount of the claim $(R 38,500)$ sought by the victim's children. Interview with Geoff Budlender, attomey for Mkize's children, at Mt. Grace Conference, South Africa (July 22, 1989). 
standing I would have awarded greater damages than I now propose to do. ${ }^{67}$

This statement clearly demonstrates the judiciary's view of the worth of a black plaintiff and serves to reinforce a pernicious mythology of racial hierarchy. ${ }^{68}$

In criminal trials, the motive for committing a crime is critical to the question of whether the accused is guilty. ${ }^{69}$ Sometimes in South Africa the accused will advance a custom or a socially accepted belief as the motive for committing a crime. An unrepresentative judiciary, ignorant of such a custom or its importance to the accused's racial group, may well regard it as mere superstitious belief and not as an integral part of an organized society. In some cases, these prejudices may lie fairly far beneath the surface of the judicial process. In a society like South Africa's, where, with few exceptions, the various races live in racially segregated areas, there is a real danger that one race may not be aware of the problems of the other races. A judge's lack of understanding of the problems of other races denies him the ability to render a decision informed by such problems.

A case in point is an unreported case in which S. Sandile Ngcobo represented a plaintiff suing for restoration of a house of which a government official had deprived him. Not appreciating the reason for plaintiff's insistence on the return of the house, the judge asked, "Why doesn't the government allocate another house to the plaintiff? Surely there must be many houses out there." The judge did not know that there were no houses in that township and that in fact there were thousands of people on the waiting list for homes.

In R. v. Nkonyane, ${ }^{70}$ an African was convicted and fined for refusing to leave his house and move into a native location. $\mathrm{He}$

67. Radebe v. Hough, 1949(1) S.A. 380, 384-85 (App. Div.).

68. See also R. v. Olakawu, 1958(2) S.A. 357, 361 (Cape. Prov. Div.), where the court upheld the criminal conviction of a black houseboy accused of writing a love letter to a white woman, explicitly noting that the difference in color between the parties was "a factor in the decision of whether a crimen injuria has been proved."

69. As recently as 1980, a former Chief Justice in South Africa stated: "Apparently the advocate for the defense and the trial court have not yet had the experience that Coloured and Black men do indeed sometimes stab people without any reason except for an apparent lust for stabbing." S. v. Augustine, 1980(1) S.A. 503, 506 (App. Div.) (quote froin translation).

70. 1944 A.D. 489 (S. Afr. App. Div.). 
contended that the government had failed to demonstrate that "reasonably adequate" accommodation was available, as was required by the Natives (Urban Areas) Act. His former residence was a fertile, fenced-in plot with a spring of water and a lavatory attached to a four-room house with an iron roof. His designated location residence was to be a four-room house, although the plot of land was one-eighth the size of his former residence, with no water or lavatory. The court noted that water was 144 yards away and " $[t]$ en communal sanitary conveniences, each with ... accommodation for five people, [were] provided for the use of the 1,600 natives in the location."71 The court dismissed the appeal.

In the similar case of $S . v$. Adams, ${ }^{72}$ the judge suggested to Adams that rather than coming to Johannesburg to look for employment, he should have instead looked for employment where there were accommodations for the Indian community so that he would not have violated the Group Areas Act. Without hesitation, the judge openly stated that blacks should quit their jobs and move away. As the judge explained:

[Adams] found it desirable to come to Johannesburg in order to find employment and to better himself. While the appellant is lawfully employed in Johannesburg, neither he nor his wife is lawfully obliged to pursue his or her employment in Johannesburg .... If [Adams] cannot avoid breaching the provisions of the Act without his and his wife's abandoning their employment in Johannesburg, then-as inequitable as it will be-he and his wife will have to seek their livelihood in another place. ${ }^{73}$

\section{THE UNITEd STATES' EXPERIENCE IN THE} APPOINTMENT OF FEDERAL JUDGES

Since the record establishes that many cases can only be explained by the personal or philosophical views of the specific judge, it is obvious that often there is an interrelationship between the judicial appointment process and the results reached in individual cases. It is therefore appropriate to analyze the United States' experience in the appointment of judges.

71. Id. at 492 .

72. 1979(4) S.A. $793 \mathrm{~T}$.

73. Id. at 800 . 
Although our present federal judicial system has many merits which any nation planning a new constitution should consider, one must start by noting that from the perspective of many Americans, for at least the first 150 years of its existence, the U.S. Constitution was not fiawless. ${ }^{74}$ Seventy years after the Constitution was drafted, Chief Justice Roger Brook Taney, in Dred Scott v. Sandford ${ }^{75}$ declared that under the Constitution, blacks "had no rights which the white man was bound to respect." and persistent shortcomings in granting equal justice to many minorities and women, one can acquire relevant insights from studying the formation of the Constitution. More important, one can gain insight from understanding the evolution of the Constitution to its present stage. ${ }^{77}$ This earlier history is particularly relevant as one attempts to ensure pluralism in the present judiciary.

During the formation of the Constitution in 1787, the problem of an unrepresentative judiciary was never discussed. ${ }^{78}$ It was an unchallengeable assumption that the courts should not be representative of the population. The Framers did not perceive that their

74. See generally A. LEON HigginbothaM, JR., IN THE MATTER OF COLOR: RACE AND THE AMERICAN LEGAL PROCESS (1978).

75. 60 U.S. (19 How.) 393 (1856).

76. Id. at 407.

77. As Justice Thurgood Marshall has observed:

When contemporary Americans cite "The Constitution," they invoke a concept that is vastly different from what the Framers barely began to construct two centuries ago.

For a sense of the evolving nature of the Constitution we need look no further than the first three words to the document's preamble: "We the People." When the Founding Fathers used this phrase in 1787, they did not have in mind the majority of America's citizens. "We the People" included, in the words of the Framers, "the whole Number of free Persons." On a matter so basic as the right to vote, for example, Negro slaves were excluded, although they were counted for representational purposes-at three-fifths each. Women did not gain the right to vote for over a hundred and thirty years.

....

What is striking is the role legal principles have played throughout America's history in determining the condition of Negroes. They were enslaved by law, emancipated by law, disenfranchised and segregated by law; and, finally, they have begun to win equality by law. Along the way, new constitutional principles have emerged to meet the challenges of a changing society. The progress has been dramatic, and it will continue.

Thurgood Marshall, Reflections on the Bicentennial of the United States Constitution, 101 HARV. L. REV. 1, 2, 5 (1987).

78. See John R. Vile \& Mario Perez-Reilly, The U.S. Constitution and Judicial Qualifications: A Curious Mission, 74 JUdiCATURE 198, 198 (1991). 
preference for "unrepresentativeness" was an assumption upon which there could be any disagreement.

The Framers were concerned more about the powers of the presidency, and the powers and the selection of the legislature, than about the structure or composition of the courts. ${ }^{79}$ By entrusting the nomination of judges to the President, and by granting the Senate the power to advise and consent to these nominations, the Framers were confident that the courts would implement, without question, the type of government the Framers desired. In fact, they were so certain that judges would be white, male, ${ }^{80}$ and privileged that they did not even prescribe those sterling qualities as prerequisites for appointment to the bench.

In contrast to the absence of criteria for selection of the judiciary in Article III, in Articles I and II the Framers explicitly set forth the requirements for obtaining the high offices of president, senator, and representative. They made it clear that they wanted to have elected to these offices individuals who would exemplify the type of person who had attended the Constitutional Convention. Thus, for the presidency, the Framers required:

No person except a natural born Citizen, or a Citizen of the United States, at the time of the adoption of this Constitution, shall be eligible to the Office of President; neither shall any Person be eligible to that Office who shall not have attained to the

79. See id.

80. Indicative of the demeaning perception of women during that era, Thomas Jefferson wrote: "Were our state a pure democracy, there would still be excluded from our deliberations ... . women, who, to prevent depravation [sic] of morals and ambiguity of issues, should not mix promiscuously in gatherings of men." MARTIN GRUBERG, WOMEN IN AMERICAN POLITICS 4 (1968) (omission in original).

As recently as 1873 , the U.S. Supreme Court held that it was not a violation of the Constitution for a state to deny a married woman the right to practice law. In a concurring opinion, Justice Joseph Bradley said:

[T] he civil law, as well as nature herself, has always recognized a wide difference in the respective spheres and destinies of man and woman. Man is, or should be, woman's protector and defender. The natural and proper timidity and dehicacy which belongs to the female sex evidently unfits it for many of the occupations of civil life. The constitution of the family organization, which is founded in the divine ordinance, as well as in the nature of things, indicates the domestic sphere as that which properly belongs to the domam and functions of womanhood. ...

... The paramount destiny and mission of woman are to fulfil the noble and benign offices of wife and mother. This is the law of the Creator. And the rules of civil society must be adapted to the general constitution of things, and cannot be based upon exceptional cases.

Bradwell v. State, 83 U.S. (16 Wall.) 130, 141-42 (1872). 
Age of thirty-five Years, and been fourteen Years a Resident within the United States. ${ }^{81}$

For the House of Representatives, the Framers provided: "No Person shall be a Representative who shall not have attained to the Age of twenty five Years, and been seven Years a Citizen of the United States, and who shall not, when elected, be an Inhabitant of that State in which he shall be chosen." ${ }^{82}$ And for the Senate, they provided: "No Person shall be a Senator who shall not have attained to the Age of thirty Years, and been nine Years a citizen of the United States, and who shall not, when elected, be an Inhabitant of that State for which he shall be chosen." 83

By contrast, the Framers articulated no criteria for selection of the judiciary; nor was representativeness a criterion for the appointment of federal judges. For our highest court-the U.S. Supreme Court-the Constitution does not even require that the Justices be lawyers. As two scholars recently observed:

While there was debate at the convention over who should appoint judges, the only other apparent mention of the subject of judicial qualifications at the convention was a joke related by Benjamin Franklin in which he noted the Scottish practice "in which the nomination proceeded from the Lawyers, who always selected the ablest of the profession in order to get rid of him, and share his practice among themselves." $\$ 4$

In The Federalist No. 78, Alexander Hamilton described the judicial branch as "beyond comparison the weakest of the three departments of power," because judges exercised "neither FORCE nor WILL but merely judgment ...." ${ }^{85}$ Hamilton could take solace from the fact that "there can be but few men in the society who will have sufficient skill in the laws to qualify them for the stations of judges" and that even those who in his view had "sufficient skill" needed to be those "who unite the requisite integrity with the requisite knowledge." $" 86$

81. U.S. CoNST. art. II, $\S 1$, cl. 4.

82. Id. art. I, § 2 , cl. 2.

83. Id. art. I, \& 3, cl. 3.

84. Vile \& Perez-Reilly, supra note 78, at 198 (quoting 1 THE RECORDS OF THE FEDERAL CONVENTION OF 1787, at 120 (Max Farrand ed., 1937)).

85. THE FEDERALIST No. 78, at 465-66 (Alexander Hamilton) (Clinton Rossiter ed., 1961).

86. Id. at 471. 
The Thirteenth Amendment, ratified in 1865, abolished slavery; the Fourteenth Amendment of 1868 guaranteed all citizens the rights of due process and equal protection; and the Fifteenth Amendment, adopted in 1870 , generally gave black males the right to vote. Prior to the adoption of these Amendments, the U.S. Constitution was an instrument of oppression rather than a covenant or protection for blacks. Loren Miller describes this profound constitutional change in the following manner:

The long sickness had come to end; now the majestic rhetoric of the Declaration of Independence had full meaning: "All men are created equal [and] are endowed by their Creator with certain unalienable Rights, that among these are Life, Liberty and the pursuit of Happiness." The "Government ... instituted among men" in the United States of America was committed to "secure these rights" and to safeguard them against the aggressions of individuals, of the states, and of their agents and servants. By constitutional fiat and statutory direction, the national writ would run to guarantee privileges and immunities, due process, and equal protection of the laws for every man, white and black. In spirit, "in all of our legislation," there was "no such word as black or white . . only . . . citizens."

Despite the dream as envisioned by Loren Miller, it was not until eighty-four years after the passage of the Thirteenth Amendment that the first black was appointed to a federal court of record in the United States. ${ }^{88}$ When President Harry Truman nominated William Henry Hastie to the U.S. Court of Appeals for

Hamilton went on, not to recommend a minimum age or other qualifications for judges, but rather to dispute with those who, following the precedent of the New York Constitution, thought judges should have to resign at age 60 . Thus, Hamilton's arguments would suggest that any opposition to judicial qualifications had come, not from those who disliked the idea of a minimum age, but from those who had raised "the imaginary danger of a super-annuated bench."

Vile \& Perez-Reilly, supra note 78, at 199 (quoting THE FEDERALIST No. 79, at 475 (Alexander Hamilton) (Clinton Rossiter ed., 1961)).

87. LOREN MILLER, THE PETTTONERS 100-01 (1966) (alteration and omissions in original).

88. When using the term "federal court," I am referring to those courts of record where judges are appointed pursuant to Article III of the Constitution. Today, these courts are the U.S. District Court, the U.S. Court of Appeals, and the U.S. Supreme Court. 
the Third Circuit in $1949,{ }^{89}$ it had been 173 years since the signing of the Declaration of Independence and 162 years since the convening of the Constitutional Convention. With regard to gender and non-representation, it took only slightly less time-147 years from the drafting of our Constitution-before the first woman, Florence Allen, was appointed to the U.S. Court of Appeals in 1934.

The present composition of the federal judiciary still demonstrates that blacks and females are significantly underrepresented. As of January 1, 1993, of the 837 authorized, active Article III judges, blacks comprised a total of $5.1 \%$, women $10.9 \%$, HispanicAmericans 3.7\%, and Asian-Americans 0.7\%. ${ }^{90}$

It is most fascinating to note the differences in the racial and gender appointments of the various presidents. ${ }^{91}$ President Truman, who appointed William Henry Hastie in 1949,92 was succeeded by President Eisenhower. During his eight years in office, Eisenhower did not appoint any black to any federal court $^{93}$ in the continental United States. President Kennedy appointed one African-American to the federal appellate courts, ${ }^{94}$ and President

89. WARE, supra note 15 , at 225,233 . Hastie was confirmed by the Senate on July 19, 1950. Id. at 240. Prior to his appointment to the Court of Appeals, Hastie had served as a territorial judge in the U.S. Virgin Islands. Id. at 85-86.

90. See infra Appendices C, D.

91. See Higginbotham, supra note 23 , at 573-75 n.460. I am indebted to Elaine Jones for her work on this issue. See Elaine R. Jones \& Janice King-Robinson, Choices: Appointing Blacks to the Federal Judiciary, NAT'L BAR Ass'N MAG., July 1988, at 16.

92. Cynthia Harrison described President Harry Truman's judicial appointment philosophy as follows:

[H] intended to keep the cabinet a male preserve. He refused to consider Frances Perkins to head the Federal Security Administration because, one of his aides reported, he intended to create a Department of Welfare, and he "did not want any woman in the cabinet." He also allowed Chief Justice Fred Vinson to veto the selection of the first woman on the Supreme Court. [India] Edwards [Chairman of the Woman's Division of the Democratic National Committee] had recommended Florence Allen, who had received her seat on the court of appeals from Franklin Roosevelt. According to aide Matthew Connelly, Truman explained: "The Justices don't want a woman. They say they couldn't sit around with their robes off and their feet up and discuss their problems." Truman also declined to appoint Florence Shientag to a vacant federal judgeship in New York, on the grounds that "her husband is already a Judge in the New York Courts and it seems to me that one Judge in the family is enough." (Shientag eventually became a judge of the family court in New York City.)

CYNTHIA HaRrison, ON ACCOUNT OF SEX: THE POLITICS OF WOMEN's Issues, 1945-1968, at 56-57 (1988).

93. See supra note 88 (discussing courts of record).

94. Thurgood Marshall, U.S. Court of Appeals for the Second Circuit. 
Johnson appointed two. ${ }^{95}$ Neither President Nixon nor President Ford appointed any blacks to the federal appellate courts.

In contrast, President Carter took significant steps in his appointments to the appellate courts. During his term of office, Carter appointed nine African-Americans, ${ }^{96}$ including the first African-American woman, Amalya L. Kearse. On the other hand, in his eight years in office, President Reagan found only one AfricanAmerican whom he deemed worthy of appointment, Lawrence W. Pierce. President Bush was able to locate only two. ${ }^{97}$

Presidents Nixon and Ford together appointed a total of nine African-Americans to the federal district courts; in twelve years, President Reagan appointed six and President Bush appointed ten. By contrast, President Carter in four years appointed twenty-nine African-Americans to the district courts. Carter appointed more blacks to the district courts in four years than Presidents Eisenhower, Nixon, Ford, Reagan, and Bush combined appointed in the course of nearly twenty-eight years.

Real differences are highlighted in a comparison of the judicial appointments of Presidents Carter and Reagan. In eight years in office, President Reagan appointed 378 federal judges, only eight of whom were black, a mere $1.8 \%$. In contrast, $14.3 \%$ of President Carter's appointments were black, as he appointed thirty-eight blacks to the federal judiciary in his four years of office. In half the number of years in office, Carter appointed more than four times as many blacks to the bench as Reagan. The statistics are equally illuminating when gender is considered. More than fifteen percent (15.5\%) of President Carter's appointments to federal courts were women, as opposed to only $8.2 \%$ for President Reagan.

Underlying these numbers was President Carter's specific institutional effort to see that women and minorities were ap-

95. Wade H. McCree, Jr., U.S. Court of Appeals for the Sixth Circuit, and Spotswood W. Robinson III, U.S. Court of Appeals for the District of Columbia.

96. Harry T. Edwards, J. Jerome Ferris, Joseph W. Hatchett, A. Leon Higginbotham, Jr., Nathaniel R. Jones, Amalya L. Kearse, Damon J. Keith, Theodore McMillan, and Cecil F. Poole.

97. Clarence Thomas and Timothy Lewis. Timothy Lewis was nominated on Sept. 17, 1992 after Judge Stephen Reinhardt's speech of May 16, 1992 and my op-ed article in the New York Times of July 29, 1992 pointed out that up to that time, Presidents Reagan and Bush together had appointed only two African-Americans to the courts of appeals. The final count for all of the Reagan-Bush appointments of African-Americans to the courts of appeals was 3 out of 116. See infra note 107 and accompanying text. 
pointed to the federal courts. As an example, by Executive Order 11,972 of February 14, 1977-issued within two months after he took office-President Carter created the United States Circuit Judge Nominating Commission. Each of the Commission's thirteen panels included members of both sexes, minority groups, and approximately equal numbers of lawyers and non-lawyers. Each panel also included at least one resident of each of the states within the geographic area of the panel. The panels were responsible for finding potential nominees and forwarding their names to the President. Standards for selection of proposed nominees also were provided. The panels were instructed to ensure that each potential nominee was a member of the bar, had integrity and good character, possessed and demonstrated "outstanding legal ability and commitment to equal justice under law," and would fill a perceived need for "training, experience, or expertise" on the court in which the vacancy existed. ${ }^{98}$

The Carter Administration demonstrated that a presidential commitment to a pluralistic court can eliminate many of the barriers that preclude female or minority representation..$^{99}$

More often than not, the values of the appointees are similar to those of the president making the appointment. Tim Weiner, writing in the Philadelphia Inquirer, noted that the appointments of Presidents Reagan and Bush "transformed the courts into a deeply conservative branch of government"100 that has the potential for shaping American society for decades. Weiner argued that the Reagan and Bush appointees "were selected after painstaking reviews of their judicial philosophies, and for their belief that the courts are the wrong vehicle for social change or political reform." 101 Not coincidentally, Weiner observed, these judges were more likely to belong to exclusive country clubs than to organiza-

98. Exec. Order No. 11,972, 3 C.F.R. $96-99$ (1977).

99. Exec. Order No. 11,972 was amended by President Carter in Exec. Order No. 11,993, 3 C.F.R. 126 (1977) and Exec. Order No. 12,059, 3 C.F.R. 180 (1978), and continued until December 31, 1982 by Exec. Order No. 12,258, 3 C.F.R. 305 (1980).

President Ronald Reagan terminated the U.S. Circuit Judge Nominating Commission in Exec. Order No. 12,305(a), 3 C.F.R. 150 (1981), thus repudiating the basic concept of pluralisin as a goal in his appointment process.

100. Tim Weiner, White House Builds Courts in Its Own Image, PHILADELPHIA INQUIRER, Oct. 7, 1990, at 1-A.

101. Id. 
tions, such as the League of Women Voters and the NAACP, that promote equal rights and participation in American society. ${ }^{102}$

The federal judiciary, in addition to becoming more conservative, has also experienced a decline in minority representation, as noted by the Alliance for Justice, a national liberal coalition. The coalition's most recent annual report stated:

Because of his failure to appoint minorities at a rate to keep up with their departure from the bench, Bush achieved no gains in placing people of color on the courts. Moreover, under 12 years of Republican rule, for the first time since an AfricanAmerican was first appointed in 1937, the number of blacks on the federal bench actually dropped. Hispanic representation increased only slightly in the last four years, and the appointment rate of Asian-Americans can only be described as snail-like. [The tables included in the Appendix show] the stagnating number of minorities on the bench over the last 12 years. ${ }^{103}$

In the United States, scholars and politicians do not doubt that judicial appointments based on viewpoint and background often affect court decisions. Nan Aron of the Alliance for Justice has noted that "the bench has grown increasingly hostile to claims brought by minorities and women."104 Professor Sheldon Goldman offers a similar assessment: "As we celebrate the bicentennial of the Bill of Rights, our courts are increasingly populated with people who take a crabbed view of our civil rights and our

102. Id. Weiner also contrasted the American experience under the Carter Administration with that under the Reagan and Bush Administrations:

Two consecutive Republican administrations have meant, as [Murray] Dickman [one of Attorney General Dick Thornburgh's top aides who screens judicial appointments] noted, that the courts are taking on a Republican appearance. Demographically, the Reagan and Bush appointees have been far less diverse than those of the most recent Democratic president, Jimmy Carter.

Carter's choices for federal judgeships were overwhelmingly liberal or moderate, and unusually diverse: More than a third of the nominees were female, black or Hispanic.

....

Of the 466 federal judges appointed by Bush and Reagan, 86 percent are Id. white men. Nine percent are women, 3 percent Hispanic and 2 percent black.

103. AllianCE FOR JUSTICE, THE Federal COURTS AT A CROSSROAdS: JUdicial SELECTION PROJECT ANNUAL REPORT 4 (1992).

104. Weiner, supra note 100 , at $1-A$. 
civil liberties." ${ }^{105}$ Conservatives themselves are hopeful that the Reagan-Bush legacy will last well into the twenty-first century. ${ }^{106}$ In a May 16, 1992 speech, Judge Stephen Reinhardt commented on this reactionary legacy:

By their appointments, Presidents Reagan and Bush have ensured that the federal courts will not be representative. Instead, they are a bastion of white America. They stand as a symbol of white power. . . . In 1976, there were only two black federal appellate judges on the bench. President Carter appointed a total of 56 judges to the federal appellate court- 9 were blacks-sixteen percent! Starting in 1980, however, Presidents Reagan and Bush dramatically reversed the course once more. In his eight years in office President Reagan made a total of 83 appointments to the federal courts of appeal[s]. During that time he succeeded in finding only one black he deemed worthy of appointment. [As of May 1992,] George Bush, with 32 appointments ..., has also been able to locate only one African-American he thought qualified to serve-in his case, guess who-Clarence Thomas-and now that Justice Thomas has been rewarded with an even higher office because of his outstanding legal abilities, there are no black Bush appointees on the Courts of Appeals. In President Bush's view, Clarence Thomas is apparently all there is out there. Clarence Thomas is black America to our President. ... And as the Carter judges age in years, we can expect the now extremely low percentage of African-American appellate judges to diminish even further-a sorry indictment of the federal judiciary .... Incidentally, the figures for Hispanics, Asians, and Native-Americans are even worse. ${ }^{107}$

105. Id. at 20-A.

106. Id.

107. Judge Stephen Reinhardt, U.S. Court of Appeals for the Ninth Circuit, Riots, Racism, and the Courts: Commencement Speech at Golden Gate University (May 16, 1992). Subsequent to Judge Reinhardt's speech and my New York Times op-ed article of July 29, 1992, as the presidential election debates on President Bush's appointment policy intensified, President Bush informed Timothy Lewis on September 16, 1992 that he was being nominated for appoimtment to the U.S. Court of Appeals for the Third Circuit. In an incredibly smooth and rapid process, Lewis had his hearing before the Judiciary Committee and was confirmed by the Senate on September 24, 1992, with Republicans and Democrats both taking credit. He was sworn in on October 23, 1992, less than six weeks after President Bush's telephone call. 
Undoubtedly, retrenchment on pluralism during the last twelve years has diminished some citizens' respect for the courts. This diminution of esteem will persist unless President Clinton makes efforts similar to President Carter's to make the judiciary more pluralistic and representative.

\section{THE NECESSITY of A VIABLE SOUTH AFRICAN BILL OF} RIGHTS AND A WIDESPREAD PERCEPTION OF JUDICIAL FAIRNESS

What is the relevance of this American experience to South Africa? On one level, it may be that South Africans would do well to recognize that the values and the politics of the person making the judicial appointment are decisive. To ensure pluralism on a court, there has to be some personal commitment by the person (in the United States, the President) making the appointment. As the citizens of South Africa confront the difficult challenge of proposing criteria for selection of judges to a constitutional court, they should evaluate the American experience and ascertain whether, and to what extent, they desire to incorporate greater specificity into the appointment process. ${ }^{108}$

On another level, the American experience is relevant to determine the function of the judiciary in a democratic society. In a democratic society, the judiciary occupies a unique position of extraordinary power. Judges are involved in the affairs of all of the people. By their decrees they determine who will live and who will die in capital punishment cases, dictate how vast amounts of resources will be allocated through civil verdicts and corporate reorganizations, and define the duties and obligations individuals will have with regard to one another in day-to-day life. Whether they like it or not, judges decide-often without clear statutory or constitutional direction-the type of justice that exists in a society.

Judges affect the lives of many more individuals than merely the parties in a particular lawsuit or judicial proceeding. The types of cases they adjudicate or decline to hear are numerous, and the impact of their decisions is enormous. Although judges may pledge to be free from any bias or other improper influence when deciding cases, this pledge may be undermined when a judiciary is racially unrepresentative. Overt or subconscious bias in favor of

108. See generally ALDISERT, supra note 9 (discussing experiences in other courts). 
one's own racial group often constitutes insensitivity to the plight of other racial groups that are not represented in the judiciary.

To speak of the criteria for the appointment of a constitutional court without first establishing an infrastructure for a viable and protective bill of rights is like designing an airplane without either wings or a motor-it will not take off. Thus, my comments on pluralism have been predicated on the assumption that the South African Constitution, which the court will be construing, protects the basic human rights of all citizens. ${ }^{109}$ This is particularly true in a country where the majority perceives the present court as having been one of the major instrumentalities for implementing the injustices legislated by a parliament whose acts were blatantly racist. It is not enough to have merely a viable bill of rights. It is essential that the structure and appointment mechanisms for a constitutional court guarantee a fair process so that the citizens will have faith in the fairness of judges and judicial decrees. ${ }^{110}$

109. The validity of this assumption depends upon (1) the existence of a constitutional infrastructure; (2) a viable South African bill of rights; and (3) an appropriately structured constitutional court. Each of these elements, however, is problematic.

First, as the recent breakdown in negotiations after the Boipatong killings makes clear, the existence of a constitution is a matter upon which South Africans as yet have not been able to agree.

Second, it is necessary to assume that which has not always been so obvious in South Africa's history-that the content of a bill of rights will be progressive and will command respect. On the one hand, for years, the South African government vehemently resisted any proposals to include a bill of rights in its legal system. Moreover, when the government's attitude showed signs of changing, many felt that the government's only interest in a bill of rights was to entrench white privilege, through the use of group rights or otherwise. DUGARD ET AL, supra note 4, at 124-25. On the other hand, since 1987, the proposition that a new South Africa would be a democracy with an independent judiciary, a bill of rights, and judicial review has been a cornerstone of anti-apartheid thinking.

Third, one must assume that the weighty questions of court structure will be resolved with due attention to the fostering of a distinctly South African constitutional culture that draws from and respects universal hunnan rights. Some proposals for a constitutional court envision a court empowered to pronounce upon the validity of legislation prior to its promulgation. Other proposals would restrict the jurisdiction of the courts to examining laws after they are passed. Some proposals call for a centralized court with exclusive constitutional jurisdiction. Still other proposals argue that a decentralized constitutional jurisdiction, with all ordinary courts able to pronounce on constitutional issues, at least in the first instance, will do more to promote a human rights culture among the population and the state bureaucracy of a new South Africa. These and other issues of court structure are questions that South Africans themselves must' resolve.

110. The actual structuring of such an essential mechanism goes beyond the scope of this paper. 


\section{CONCLUSION}

A judiciary that is always unrepresentative of the population's racial groups and that basically excludes women is bound, at its best, to lack credibility, and, at its worst, to be partisan. This is especially true in a country where institutionalized racism is legitimized as a way of life. The bench is more likely to uphold, often even subconsciously, the prejudices of the race it "represents," particularly when given the discretion to make value judgments. Lack of an understanding of other cultures and the plight of other racial groups often causes a court, however unintentionally, to render decisions that have an acute detrimental impact on other races. Such a judiciary is suspect because it must sit in sole judgment when the laws enacted by its racial group are challenged by the legally disfranchised. In almost every country there will be a few judges who are decades ahead of their contemporaries when viewing matters of racial and social justice. It strains credulity, however, to suggest that a judicial system in which the rule of law has been so racist and so vengeful can be changed into a tool for social justice without a major restructuring of the appointment process. In any country, there can be true justice only if there is commitment to equal justice for all. Indeed, it is too much to

In a letter to Judge A. Leon Higginbotham, Jr., Sandile Ngcobo notes the adverse impact which the current method of selecting Supreme Court judges in South Africa has on the appointment of black judges:

[T] he present practice is to appoint judges froun the ranks of the so-called Senior Counsels, ... barristers who have been in practice [for a substantial period]. Taking the silk, as becoming Senior Counsel is professionally referred to, is by itself no easy matter. To become eligible, the current tradition requires that you display a broad range of experience in the area of civil law. Black barristers are by tradition excluded from getting any significant experience in the areas of civil law....

... As of April, 1989, there were at least 863 practicing barristers in South Africa. Of this figure, there were 145 senior counsels. As of that date, there were only 2 Asian senior counsels. As of today, there is one African silk. Of the total number of practicing barristers there were 25 African barristers. ... [O]nly two have been in practice for more than 18 years. Of the remaining, about five have been in practice for more than 10 years, but less than 14 years, and their practices have been largely criminal.

Given the linited number of practicing black barristers as well as pervasive discrimination in the hiring of barristers, if the present method [of] appointing judges continues in future South Africa, the probabilities are that the judiciary will for a considerable period of time, remain predominantly white in a country which is predominantly black. The present method of appointing judges will thus serve to perpetuate a racially structured judiciary. The urgent question, therefore, is how can this situation be prevented.

Letter from S. Sandile Ngcobo to A. Leon Higginbotham, Jr. (Oct. 9, 1990) (on file with author). 
expect that a judiciary that is neither pluralistic nor reasonably representative will frequently provide full justice in cases that challenge the status quo. The cumulative effect of a court's harshness in the past undermines the public confidence that is critical to the integrity of the judiciary and to the public's respect for the rule of law.

In understanding the challenges of creating a viable, fair, and pluralistic constitutional court and an effective bill of rights, answers may be found more easily in language that does not appear in legal documents or judicial rulings. The writings of poets and philosophers may offer more insights than the prestigious documents that bear the imprimatur of the United Nations or documents such as the European Convention of Human Rights and the German, Irish, Italian, or U.S. Constitutions.

Let me start with the words of a poet who I think put in broader context the challenges the nations of the world face today when seeking to secure equal justice under the law. These words were uttered before the United Nations was established in 1945 and before Jan Smuts drafted its preamble. They were uttered before the creation of the League of Nations, and long before the Republic of South Africa came into being. They are the words of Shakespeare, as spoken by Shylock in The Merchant of Venice:

He hath disgraced me... scorned my nation ... cooled my friends ... heated mine enemies, and what's his reason? . . . If you prick us, do we not bleed? If you tickle us, do we not laugh? If you poison us, do we not die? And if you wrong us shall we not revenge? If we are like you in the rest, we will resemble you in that .... The villainy you teach me I will execute, and it shall go hard but I will better the instruction. ${ }^{111}$

Shakespeare's expression captures the fears of all persons who are or have been oppressors. They fear that the villainy of past governments may be "bettered" by a new majority government. They fear that the cruelty that has been perpetrated by the misallocation of economic resources such that thirteen percent of the people have eighty-seven percent of the wealth may be drastically reversed. They fear that a future majority may find merit in the duplication of the type of repressive laws from which the oppres-

111. William Shakespeare, The Merchant of Venice act. III, sc. I, lines 46-62, in THE COMPLETE WORKS (Stanley Wells \& Gary Taylor gen. eds., 1988) (1600). 
sors once benefitted. They fear that the lessons of the past may not be forgotten and may be applied against those who once were the beneficiaries of villainy that made many black South Africans fearful and almost powerless.

I cannot believe they are fearful of Nelson Mandela as a person. They know he is a not a madman and that in any one hour, he has spoken more sense than P.W. Botha spoke in his entire lifetime. What they fear is that a new South African legislature will revive the lengthy detentions that the courts once said they could do nothing about because of parliamentary supremacy.

They are fearful that freedom of speech will be denied to former oppressors in the ruthless fashion in which they once denied basic human rights to all others. They are fearful that the great writ of habeas corpus will be denied to them just as they have precluded millions of black South Africans from judicial relief. They are fearful that a new state would activate the concepts of treason that could cause them to languish in prison for years, as Nelson Mandela had. They are fearful that a judicial system that sanctioned the taking of Steven Biko's life might be turned on them. They are fearful of a system that caused hundreds of black lawyers and their committed white allies to wonder whether in the next day, the next week, or the next month security or police would knock on their door and take them away on trumped-up charges for which there is no probable cause and no justification.

These are fears that cannot be disregarded in planning a new constitution. In my mind, the past must not be a prologue for the future. South Africa must have a bill of rights that is protective and not punitive; and we in the United States must make our Bill of Rights more viable and effective for our citizens who are poor and dispossessed. Americans want to see South Africa build a rule of law that is brighter, fairer, and more just than South Africa has ever known before. But Americans must also want to improve the justice system in this country so that the type of brutality Rodney King suffered in Los Angeles will not be sanctioned, even implicitly, by our legal system. ${ }^{112}$ Neither South Africans nor Americans

112. For a more detailed discussion of the significance of the events involving Rodney King, see A. Leon Higginbotham, Jr. \& Aderson Bellegarde Francois, Looking for God and Racism in All the Wrong Places, 70 DENV. U. L. REV. 191 (1993). 
who care should fail in the pursuit of a truer justice that is of, by, and for all of the people.

In the process of seeking justice, we must focus on pluralism in our courts. But surely we will fail if we think that the only issue is racial pluralism. We will also fail if we think that the substitution of an all-black court for a formerly all-white court is the answer. In our judiciary, we need whites and blacks, males and females. We need as much expertise as possible in identifying persons of positive values who are willing to implement a fair system that is supportive of building a non-racial society and who also understand the complexity of administering a court.

I am not suggesting that South Africa replicate our entire system. South Africa should study and understand both the substantive and the administrative system of our federal courts, examine our Federal Judicial Center, and learn about our efforts to train new nominees on how to become good judges. The training of the judiciary must be broad in scope, from the protection of human rights to the entitlements of corporations, from implementing a fair criminal justice system to mastering the intricacies of administrative law. We must never forget that the mere elimination of apartheid gives no guarantee that a judicial system will run efficiently.

We must not delude ourselves into thinking that the public will in the long run have any confidence in a system that is ultimately unfair. Recently, I talked to a distinguished dean of a great law school in a nation that has had its independence for decades, and he advised me of the horrors in his country-incredible court delays of four or five years for the prosecution of major criminal cases, and sometimes more than a decade of delay in civil litigation. That country's judicial system is in peril-not because of a lack of pluralism in its courts, but because of a lack of efficiency in its judicial management of cases and its shortage of judicial manpower. Similar tragedies could happen in the United States or in South Africa.

While in this Article I have spoken of the past and present inequities in the United States and in current South Africa, I am not unduly pessimistic for the future. Although much more has to be done, and although there has been some slippage in the United States in the past twelve years on many basic civil rights issues, the issue of pluralism nevertheless has become an integral part of the debate on what should be the composition of the American 
federal judiciary. ${ }^{113}$ Cases such as Brown v. Board of Education $^{114}$ and Baker v. Carr ${ }^{115}$ and their progeny demonstrate our system's remarkable capacity for change and improvement during the last fifty years. I believe that it is possible for persons of good will to build a non-racial society and a non-racist court system. In 1993, we can build new nations and new court systems that will be fairer and more just than ever before. In order to do this in the 1990s, we must remember the lessons of the past. We must not act as if we believe in the folly of Gilbert and Sullivan's Lord Chancellor:

The Law is the true embodiment

Of everything that's excellent.

It has no kind of fault or flaw,

And I, my Lords, embody the Law. ${ }^{116}$

113. See supra Part III.

114. 347 U.S. 483 (1954).

115. 369 U.S. 186 (1962).

116. W.S. GILbERT \& ARTHUR Suluvan, IOLANTHE act I, no. 7, Song of the Lord Chancellor (1882). 


\author{
APPENDIX $\mathrm{A}^{117}$ \\ BREAKDOWN OF THE FEDERAL JUDICIARY \\ BY COURT AND PRESIDENT \\ (as of November 1, 1992)
}

\begin{tabular}{|c|c|c|c|c|c|c|c|c|c|c|c|c|c|c|c|c|c|c|c|c|}
\hline \multirow{3}{*}{$\begin{array}{l}\text { Suprems } \\
\text { court } \\
\text { Cireults }\end{array}$} & \multicolumn{2}{|c|}{ Vacancies } & \multicolumn{2}{|c|}{ Bush } & \multicolumn{2}{|c|}{ Reagan } & \multicolumn{2}{|c|}{ Carter } & \multicolumn{2}{|c|}{ Ford } & \multicolumn{2}{|c|}{ Nixon } & \multicolumn{2}{|c|}{ Johnson } & \multicolumn{2}{|c|}{ Kennedy } & \multicolumn{2}{|c|}{ Elsenhower } & \multicolumn{2}{|c|}{ Truman } \\
\hline & \multicolumn{2}{|c|}{0} & \multicolumn{2}{|c|}{2} & \multicolumn{2}{|c|}{4} & \multicolumn{2}{|c|}{0} & \multicolumn{2}{|c|}{1} & \multicolumn{2}{|c|}{1} & \multicolumn{2}{|c|}{0} & \multicolumn{2}{|c|}{1} & \multicolumn{2}{|c|}{0} & \multicolumn{2}{|c|}{ o } \\
\hline & Crat & Doutlat & Crak & Dowtat & Cran & Distriat & orats & axtsict & Crant & Desticic & cratt & Diatrict & Crant & Osstict & reaft & Ditstet & Creart & Destrict & crant & Detrad \\
\hline D.C. & 1 & $\overline{3}$ & 2 & 0 & 5 & $\overline{6}$ & 4 & 4 & 0 & 0 & 0 & 1 & 0 & $t$ & 0 & $\overline{0}$ & 0 & 0 & 0 & 0 \\
\hline Flat & 0 & 4 & 3 & 8 & 2 & 11 & 1 & 7 & 0 & 0 & 0 & $t$ & 0 & 0 & $\overline{0}$ & 0 & 0 & 0 & 0 & 0 \\
\hline second & 1 & 11 & 3 & 13 & 6 & 23 & 2 & 7 & 1 & 2 & 0 & 4 & 0 & 1 & 0 & 0 & 0 & 0 & 0 & 1 \\
\hline Third & 2 & 4 & 3 & $\pi$ & 8 & 26 & 1 & 11 & 0 & 3 & 0 & 1 & 0 & 0 & 0 & 0 & 0 & 0 & 0 & 0 \\
\hline Fourth & 2 & 6 & 4 & 15 & 2 & 20 & 4 & 7 & 1 & 2 & 2 & $t$ & 0 & 1 & 0 & 0 & 0 & 0 & 0 & 0 \\
\hline Fith & 4 & 12 & 4 & 18 & 7 & 28 & 2 & 20 & 0 & $T$ & 0 & 0 & 0 & $t$ & 0 & 0 & 0 & D & 0 & 0 \\
\hline slxth & 2 & 8 & 3 & 11 & 6 & 25 & 5 & 16 & .0 & 0 & 0 & $T$ & 0 & 1 & 0 & 1 & 0 & 0 & 0 & 0 \\
\hline Soventh & 0 & 4 & 1 & 6 & 7 & 24 & 1 & 9 & $T$ & 1 & 0 & 1 & 1 & 0 & 0 & 1 & 0 & 0 & 0 & 0 \\
\hline Elghth & 0 & 9 & 3 & 10 & 6 & 17 & 2 & 7 & 0 & 0 & 0 & 0 & 0 & D & 0 & 0 & 0 & 0 & D & 0 \\
\hline Ninth & 0 & 10 & 4 & 25 & 10 & 42 & 12 & 18 & 0 & 1 & 1 & 2 & 0 & 1 & 1 & 0 & 0 & D & 0 & 0 \\
\hline Tenth & 2 & 3 & $T$ & 10 & 6 & 9 & 3 & 11 & 0 & 2 & 0 & 2 & 0 & D & 0 & 0 & 0 & 0 & $\overline{0}$ & 0 \\
\hline Eleventh & 1 & 10 & 4 & 16 & 2 & $\overline{18}$ & 3 & 12 & 2 & $\mathbf{T}$ & 0 & 7 & 0 & 0 & 0 & 1 & 0 & 0 & 0 & 0 \\
\hline Foderal & 1 & & 5 & & 4 & & 1 & & 0 & & 0 & & $\overline{0}$ & & 0 & & $\mathbf{t}$ & & 0 & \\
\hline TOTAL & 16 & 84 & 40 & 145 & 71 & 247 & 41 & 129 & 5 & 13 & 3 & 21 & 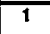 & 6 & 1 & 3 & 1 & $\overline{0}$ & 0 & 1 \\
\hline $\begin{array}{l}\text { GRAND } \\
\text { TOTAL }\end{array}$ & (11 & $\begin{array}{l}0 \\
9 \%)\end{array}$ & 1 & 18) & $\begin{array}{r}3 \\
(38\end{array}$ & 5\%) & (20) & 3\%) & & & & & & & & & & & & 1\%) \\
\hline
\end{tabular}

117. ALLIANCE FOR JUSTICE, supra note 103, table 1.

For earlier data, studies, and biographical data on African-Americans appointed to the federal courts, see THE FEDERAL BAR Association, JUST tHE BEGINNING: A CELEBRATION OF THE INTEGRATION OF THE FEDERAL JUDICIARY (1992) [hereinafter JUST THE BEGINNING].

I am indebted to the Alliance for Justice, particularly to Nan Aron and George Kassouf, for their collection of recent data. All persons concerned about racial pluralism in the courts are imdebted to the senior legal historian of the National Bar Association, Judge Edward B. Toles, for his decades of data accumulation and reporting, and advocacy to increase the number of appointments of African-American judges. See his seminal articles Centennial Anniversary Report, Negro Federal Judges (1863-1960), and Negro Federal District Court Judges Now, as reprinted in JUST THE BEGINNING, supra, at 7, 11, 24. I owe a special thanks to Elame R. Jones, Director of the NAACP Legal Defense Fund and Janice King-Robinson for their article, Choices: Appointing Blacks to the Federal Judiciary, NAT'L BAR Ass'N MAG., July 1988, at 17, 18. Also, a special thanks to Judges W. Thomas Rosemond, Jr., Joan B. Gottschall, Ann Williams, and James L. Watson for their research and reports in this area. 


\author{
APPENDIX $B^{118}$ \\ RACE AND ETHNICITY \\ BREAKDOWN OF JUDICIAL APPOINTMENTS BY PRESIDENT
}

\begin{tabular}{|l|c|c|c|}
\hline & $\begin{array}{c}\text { African- } \\
\text { Americans }\end{array}$ & $\begin{array}{c}\text { Hispanic- } \\
\text { Americans }\end{array}$ & $\begin{array}{c}\text { Aslan- } \\
\text { Amerlcans }\end{array}$ \\
\hline $\begin{array}{l}\text { Bush (194) } \\
1989-1992\end{array}$ & $\begin{array}{c}11 \\
(5.7 \%)\end{array}$ & $\begin{array}{c}8 \\
(4.1 \%)\end{array}$ & $\begin{array}{c}1 \\
(0.5 \%)\end{array}$ \\
\hline $\begin{array}{l}\text { Reagan (378) } \\
1981-1988\end{array}$ & $\begin{array}{c}7 \\
(1.8 \%)\end{array}$ & $\begin{array}{c}13 \\
(3.4 \%)\end{array}$ & $\begin{array}{c}2 \\
(.5 \%)\end{array}$ \\
\hline $\begin{array}{l}\text { Carter (258) } \\
\text { 1977-1980 }\end{array}$ & $\begin{array}{c}37 \\
(14.3 \%)\end{array}$ & $\begin{array}{c}16 \\
(6.2 \%)\end{array}$ & $\begin{array}{c}2 \\
(.6 \%)\end{array}$ \\
\hline $\begin{array}{l}\text { Ford (65) } \\
\text { 1974-1976 }\end{array}$ & $\begin{array}{c}3 \\
(4.6 \%)\end{array}$ & $\begin{array}{c}1 \\
(1.5 \%)\end{array}$ & $\begin{array}{c}2 \\
(3.1 \%)\end{array}$ \\
\hline $\begin{array}{l}\text { Nixon (227) } \\
\text { 1969-1974 }\end{array}$ & 6 & $\begin{array}{c}2 \\
(2.7 \%)\end{array}$ & $\begin{array}{c}1 \\
(.4 \%)\end{array}$ \\
\hline
\end{tabular}

118. Currently, 837 Article III judgeships exist among the district courts (649), courts of appeals (including the Federal Circuit) (179), and Supreme Court (9). This breakdown does not include appointments to the International Court of Trade, Claims Court, Tax Court, Court of Military Appeals, Court of Veteran Appeals, D.C. Court of Appeals and D.C. Superior Court. A President's elevation of one of his earlier appointees is not counted twice. ALLIANCE FOR JUSTICE, supra note 103, table 2. 
APPENDIX $C^{119}$

MINORITIES IN THE FEDERAL JUDICIARY

FROM 1976 THROUGH 1992

\begin{tabular}{|c|c|c|c|c|}
\hline & $\begin{array}{c}1976 \\
(534 \text { seats })\end{array}$ & $\begin{array}{c}1981 \\
(686 \text { seats })\end{array}$ & $\begin{array}{c}1989 \\
(752 \text { seats })\end{array}$ & $\begin{array}{c}1992 \\
(837 \text { seats })\end{array}$ \\
\hline African-Americans & 18 & 49 & 46 & 43 \\
\hline $\begin{array}{c}\text { Hispanic- } \\
\text { Americans }\end{array}$ & 5 & 19 & 31 & 35 \\
\hline Asian-Americans & 3 & 4 & 5 & 6 \\
\hline
\end{tabular}

119. Id. table 3. 


\section{APPENDIX $D^{120}$}

GENDER BREAKDOWN OF JUDICIAL APPOINTMENTS BY PRESIDENT

\begin{tabular}{|l|c|}
\hline & Women \\
\hline $\begin{array}{l}\text { Bush (194) } \\
1989-1992\end{array}$ & $\begin{array}{c}36 \\
(18.5 \%)\end{array}$ \\
\hline $\begin{array}{l}\text { Reagan (378) } \\
1981-1988\end{array}$ & $\begin{array}{c}31 \\
(8.2 \%)\end{array}$ \\
\hline Carter (258) & $\begin{array}{c}40 \\
1977-1980\end{array}$ \\
\hline $\begin{array}{l}\text { Ford (65) } \\
\text { 1974-1976 }\end{array}$ & $\begin{array}{c}1 \\
(1.5 \%)\end{array}$ \\
\hline $\begin{array}{l}\text { Nixon (227) } \\
\text { 1969-1974 }\end{array}$ & $\begin{array}{c}1 \\
(.4 \%)\end{array}$ \\
\hline
\end{tabular}

120. Id. table 4 . 